\title{
2003 年十勝沖地震時における漁民の避難行動に関する実態調査
}

\author{
田中亮平* ・河田惠昭**・井上雅夫*** \\ 原田賢治****・高橋智幸*****
}

2003 年 9 月 26 日に発生した十勝沖地震を対象として, 地震時の漁民および漁業組合の行動, また避難した漁民への情報伝 達などの実態をアンケート調査と現地調查を行うことによって明らかにしようとした。その結果，低価格の漁船や小型漁船 を保有する漁民の避難割合が低いこと，また，漁港に駆けつけた漁民は，漁船の様子を確認し，自船を避難させるか否かを 決定していることが明らかになった。これらの行動は個人の判断に委ねられているのが現状であり，漁船避難を支援した漁 業組合は少ない。 また, 情報伝達手段として, 携帯電話を用いている漁民が多いため, 洋上で情報から孤立する可能性があ り，災害時における漁業無線の有用性を指摘した。

\section{1. 緒言}

漁業関係者にとって漁船は生命に勝るとも劣らない貴 重な財産であり，津波から漁船を守るために自船を沖に 避難させたいと考えるのが普通である. しかし，漁船避 難は漁船そのものが遭難する可能性があるうえに，漁船 が漂流物となって市街地を襲うことも考えられる．した がって, 漁船避難の的確な支援システムの構築が早急に 望まれている。このためには，まず，地震発生時の漁民 の行動を把握しておかなければならない. 従来, 早瀬ら （1984）, 山本ら（1985）は日本海中部地震時, また, 河 田ら（1994）は, 北海道南西沖地震時の漁民の行動を調 査分析しているが，これらの研究では，各漁民が沖へ避 難する判断基準が明らかにされてはいない.

こうしたことから本研究では，2003 年 9 月 26 日に発 生した十勝沖地震を対象として, 地震時の漁民および漁 業組合の行動, また，避難した漁民への情報伝達などの 実態をアンケート調査と現地調査によって明らかにしょ うとした。

\section{2. 漁業組合に対するアンケート調查}

\section{（1）調查方法}

2003 年十勝沖地震が発生した直後, 津波警報が発令さ れた地域にある 19 の漁業組合を対象として,アンケート 調查を行った。その主な調查内容は，1）地震時の対応， 2）漁港内に停泊していた漁船の避難率，3）漁業保険加 入率, 4）地震時対応マニュアルの作成状況, 5）津波避難 訓練の実施状況である。

\section{（2）漁業保険と漁船加入率}

調査対象とした 19 の漁業組合のうち，18 の漁業組合 から回答が得られた。図一1には, 漁業組合ごとの漁業保 険加入率を示した。これによると，漁業保険の加入率は

\footnotetext{
$*$ 正会 員 修(工) 大阪符鳳土木事務所 技師

** フェロー 工 博 京都大学教授 防災研究所

*** $\quad$ 丁. 博

**** 正 会 員 博(工) 京都大学防災研究所 $\mathrm{COE}$ 研究員

***** 正 会 員 博 (工) 秋田大学助教授 工学資源学部
}

全体で $91 \%$ あ゙あ，加入率は非常に高いことがわかる。 また, 図一2には, 地震時に港内に停泊していた船舶の 避難率を漁業組合ごとに示した。これによると，漁業組 合によってばらつきがみられるが, 全体では $71 \%$ 高い 避難率であることがわかる。このことは，地震発生時刻 が午前 4 時 50 分であり, 漁民の活動時間であったことが 理由として挙げられる。.また，この北海道南部は，津波 常襲地帯であり，漁業関係者の間で津波に対する危機意 識が高いためと思われる.

これらの結果から, 漁業保険の加入率が高いにも関ら ず，避難率も併せて高いことがわかる．漁業保険に加入 していれば，津波による漁船被災を補償してくれると考 えるのが普通であるが，なぜ，漁民が津波来襲前に危険 を冒してまで，沖へ避難させるのであろうか．これにつ いては, 後述の現地調査の結果で明らかにしよう.
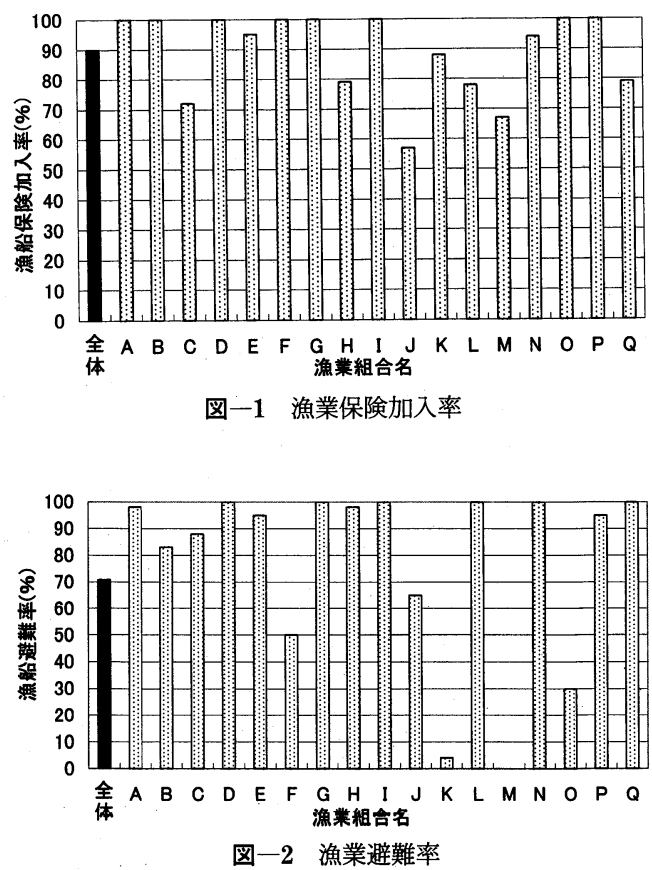


\section{（3）地霣時の漁業組合の対応}

図一3には, 地震発生直後に, 漁業組合加ら漁民へ情報 伝達をした割合を示した。これによると, 漁業組合から 組合員に対して何らかの情報を伝達したのは, 18 漁業組 合のうち 7 漁業組合に留まり, 半数にも達していない. したがって, 漁業組合から漁民に伝達された津波情報を 得てからでは, 沖へ避難できないのはやむを得ないが, 沖に避難した漁民, または出漁中の漁民に対しては, 何 らかの対応をしていかなければならない。

\section{（4）避難マニュアルの作成}

地震時における漁業組合の避難マニュアルは，2 漁業 組合でしか作成されていないのが現状であった。そのた め, 漁民に対して地震時に情報が伝達されていないのか もしれない. 作成していない 16 漁業組合のうち, この地 震を機に作成しょうと考えているのは 3 漁業組合であ り, 残りの 13 漁業組合については, 作成の予定もなしと 回答している.

图一4には，マニュアルの作成予定がない理由を示し た. 必要なしと回答しているのが 3 漁業組合, 金銭的に 困難が 1 漁業組合，技術的に困難が 5 漁業組合およびそ の他と回答したのが 4 漁業組合であった，その他の回答 では, マニュアル化しても津波の来襲が早い場合には, マニュアルが無意味である, 町の防災無線で漁業者へ情 報を周知できるので必要ない, 津波に対する知識は慣習 的に知っており, 個人で対応すべきことである, 漁業組 合から連絡している時間などないというような回答が得 られた。すなわち, 避難に対する時間的問題と漁民個人 の問題であることを理由に, 地震時対応マニュアルは必 要でないと考えている漁業組合が多いことが明らかに なった。

\section{（5）津波避難訓練の実施}

図一5には, 津波避難訓練の実施の有無を示した.これ によると、 3 割の漁業組合でしか漁船を対象とした津波 避難訓練を行っていないことがわかる. この要因として は次の 3 つのことが考えられる.まず, 津波常襲地域で
あり，漁民が津波に対して危機意識を持っているため， 避難訓練を行う必要性のないことである. 次に, 火災避 難と違って, 地震時に漁船を避難させるのは, 個人の判 断で行うことである。 そのため, 漁業組合が漁民を対象 として避難訓練を行う必要がないと考えている.最後に, 避難訓練を行ったとしても, 実際には, 津波の来襲まで に時間的な余裕がないため, 避難訓練を実施しても意味 がないと考えていることである. 津波常襲地域でさえ， 津波は, 数年に 1 度という短い間隔で発生するわけでは ない. そのため, 日頃から津波に対する危機意識を有し ていなければ, 津波来襲時には, 適切な避難はできない 可能性があることを銘記すべきである。

\section{3. 漁民に対するアンケート調査}

\section{(1) 調查方法}

巨大地震が発生すると, 漁民は津波から自船を守るた めに, 沖へ自船を避難させると言われている. しかし, 実際に漁民は何を判断して行動しているのかは明らかで ない. そのため, 漁民に対してアンケート調査を行うこ とにより,この疑問を明らかにしようとした。調查対象 としては, 漁業組合の指示で漁船が沖へ避難した地域, また津波によって，漁船が被災したと新聞などで報道さ れた地域からそれぞれ 2 漁業組合ずつ選定した。調査方 法としては, 各漁協へ 50 部ずつ郵送し, 漁協から漁民へ 配布してもらう形式をとった。 なお, 各漁業組合へ 2003 年 10 月 25 日に発送し, 同年 11 月下旬に締め切った。

その主な調査内容は，1）属性, 2) 所有船籍の形態, 3) 漁業保険への加入状況, 4) 地震発生時の居場所, 5）漁船 を避難させた理由, 6）漁船を避難させなかった理由, 7) 避難した地点の水深などである.

\section{（2）アンケートの集計結果}

全体で 200 部を配布したが, そのうち, 回収できたのは 64 部で, 回収率は $27 \%$ で非常に低い.この理由としては, 漁民へのアンケート用紙の配布を漁業組合を介して行っ たことが大きな要因として考えられる，漁業組合によっ

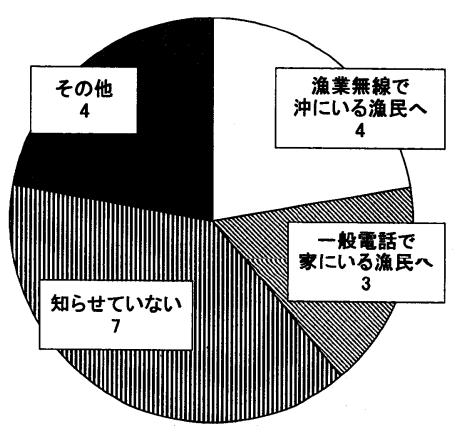

図一3 地震発生直後の組合から漁民へ の情報伝達

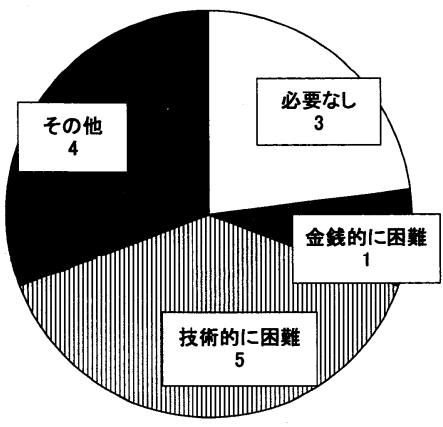

图一4 マニュアルを作成しない理由

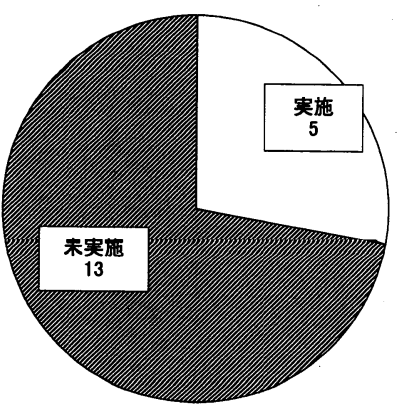

図一5 津波避難訓練の実施状況 
て, 回答者数に偏りがあるため, 有効回答が得られた 54 人すべてのデータをもとに考察を行うことにした. 考察 を行うにあたり, 地震時に漁民がとった行動を (1) 漁港 へ行かなかった,（2）漁港へは行ったが, 沖へ避難させ なかった，(3）沖へ避難させた，（4）地震時に出漁して いた，という 4 つのパターンに分類した。

\section{（3）漁港へ行かなかった漁民}

表一1には, 漁港に行かなかった 12 人の結果を示し た. 年齢に注目すると, 60 代や 70 代以上の高齢者だけが 地震直後に漁港に行かなかったのではなく, 20 代や 30 代の漁民もいる.すなわち，これらの漁民は体力的な理 由で漁港に行かなかったのではない. 次に, 漁船価格に 着目すると, 500 万円以上の漁船を保有している人もい るが, 100 万円以下の船主の割合が 7 割を占めているこ とがわかる.また, 総トン数については, $2 \mathrm{t}$ 末満の漁船 が 8 割を占め, 小さな漁船であるため, 津波来襲時に沖 へ避難させることは危険であると判断した結果なのかも しれない. 漁民にとって漁船は, 生命に優るとも劣らな い貴重な財産であると言われているが, 小型漁船を保有 している漁民にとっては, 漁船は生命に勝るものではな いと言える. また, 被害状況は, 係留策が切れたものが 一件と, 船体の一部損傷という軽度の被害に済んでいる ので, これらの漁民の判断は正しかったものと言える.

\section{（4）漁港へ行ったが沖へ避難させなかった漁民}

漁港へ行ったが, 沖へ避難させなかった漁民は 15 人で あった。図一6には，そのうち 14 人から得た地震時に自 船を沖に避難させなかった理由を示した。実際に漁港に 行き, 危険を感じたため沖へ避難させなかったと回答し た人が半数を占めているが，これは，津波警報が発令さ れていたので, 沖へ避難させれば自分の命が危険である と判断した結果と思われる。逆に, 安全と判断したため に, 沖へ避難させなかったという意見もある.この理由 としては, 自船を上架させているので, 津波が来襲して も自分の船は大丈夫であると判断した結果と考えられ る.また, 自船を沖へ避難させたくても, 消防団員であ るために, 避難させることができなかった人もいる。こ の場合には, まず自船の状態を確認してから, 消防団員 として津波対策を行ったものと思われる。

すなわち, 漁民が地震発生後, 漁港へ行き, 船や漁港 の様子を自分の目で確認することにより，このまま自船 を漁港に放置しても大丈夫であると判断して沖へ避難さ せなかったものと, 沖へ自船で自分が避難したら危険で あると判断したため避難させなかったという両極の回答 があることは大きな特徴である。

\section{（5）沖へ避難させた漁民}

沖へ避難させたと回答した漁民は 12 人であり, その埋 由を図一7に示した。船の危険を感じたものが $55 \%$ 占
めているが, これは, 津波注意報や警報が発令されてい るので, このまま漁港に自船を置いておけば, 津波によ る被害を受けると判断したために, 沖へ避難させたもの と考えられる.また，教訓と記したものは，巨大地震が 発生すると津波が来襲するので, 他の情報に頼らず, 地 震発生直後に漁港に駆けつけて沖に避難させたものであ る.

図一8には, 避難地点の水深を示した.これには出漁し ていたものと併せて示している. 沖へ避難させたものの $64 \%$ が, $20 \mathrm{~m} \sim 30 \mathrm{~m}$ 付近で待機していたことがわかる. これらすべての漁船に損傷がなかったことから，この水 深の地点に待機していれば, 今回の津波から安全に免れ ることができたと言えよう.また，図一9 には避難時間を 示した.これにも出漁していたものを併せて示した. 避 難水深のような顕著な特徴はなく, かなりのばらつきが 見られる.この事実は, 漁業組合が帰港の指示を行った

表一1 地震発生後漁港に行かなかった漁民

\begin{tabular}{c|c|c|c|c|c}
\hline 年齢 & 購入時期 & 様式 & 漁船価格 & 総卜ン数 & 被災状況 \\
\hline 30 代 & 9 年前 & 新品 & 500 万円 & $1.7 \mathrm{t}$ & 係留索 \\
\hline 20 代 & 15 年前 & 新品 & 80 万円 & $0.8 \mathrm{t}$ & なし \\
\hline 70 代以上 & 3 年前 & 新品 & 80 万円 & $2 \mathrm{t}$ & なし \\
\hline 40 代 & 13 年前 & 新品 & 70 万円 & $0.9 \mathrm{t}$ & なし \\
\hline 50 代 & 7 年前 & 中古品 & 80 万円 & $2 \mathrm{t}$ & なし \\
\hline 60 代 & 今年 & 新品 & 85 万円 & $0.9 \mathrm{t}$ & なし \\
\hline 60 代 & 5 年前 & 新品 & 75 万円 & $1 \mathrm{t}$ & なし \\
\hline 40 代 & 7 年前 & 新品 & 90 万円 & $1 \mathrm{t}$ & なし \\
\hline 50 代 & 18 年前 & 新品 & 不明 & $0.8 \mathrm{t}$ & なし \\
\hline 50 代 & 10 年前 & 新品 & 1800 万円 & $5 \mathrm{t}$ & なし \\
\hline 40 代 & 10 年前 & 中古品 & 500 万円 & $5 \mathrm{t}$ & 一部破損 \\
\hline 60 代 & 今年 & 新品 & 200 万円 & $1 \mathrm{t}$ & なし \\
\hline \multicolumn{7}{|c|}{}
\end{tabular}

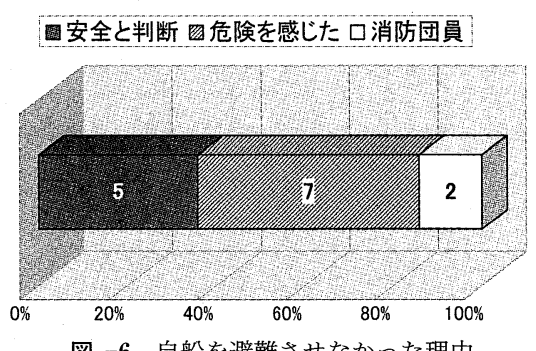

図一6＼cjkstart自船を避難させなかった理由

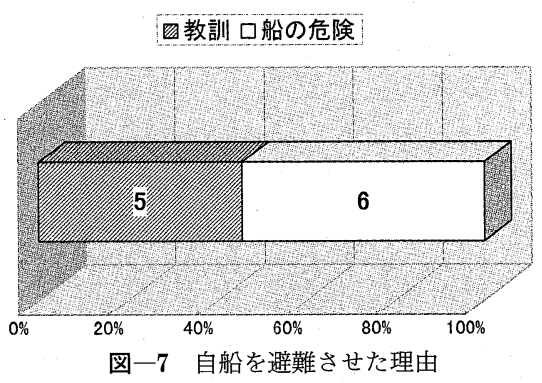




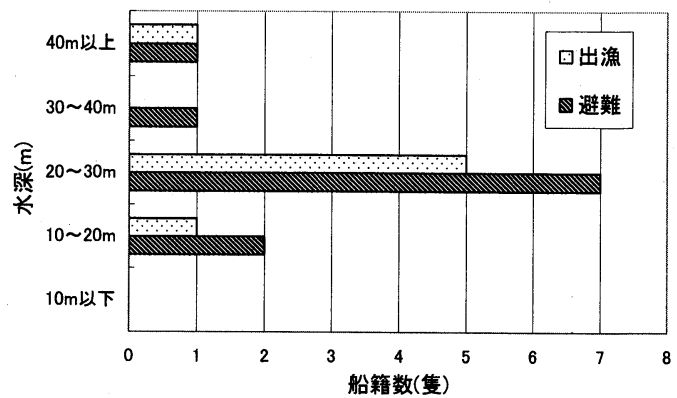

図一8 避難した地点の水深

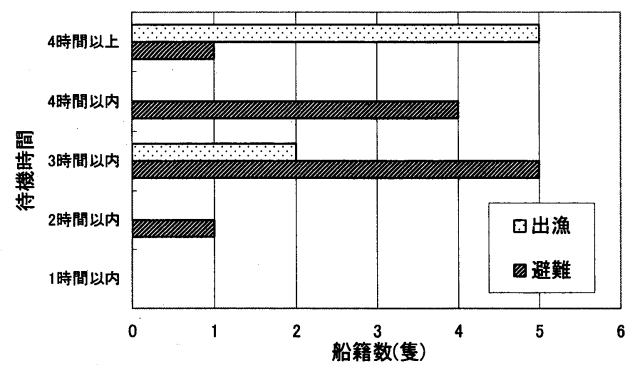

図一9 避難した地点での待機時間

わけではないことを示しており，個人の判断で帰港した ものと思われる，そのため，洋上で情報から孤立した漁 民にとっては，帰港の際に危険が伴う。

\section{（6）漁に出ていた漁民}

漁に出ていたのは 15 人であったが, そのうちの 3 人が 洋上で海震を感じたため, 身の危険を感じ帰港している. しかし，慌てていたためか，係留策が切れたり，船体の 一部が損傷したりしている.また, 図一8に示したように 待機地点の水深を見ると, $20 \mathrm{~m} \sim 30 \mathrm{~m}$ の間が多いことが わかる. 待機時間に関しては, 図一9に示したように, 3 時間以内と 4 時間以上が多い.これは, 避難後に漁を続 けたかどうかによるものと思われる．津波の来襲後，漁 を切り上げて帰港した人が 3 時間以内の待機であり, 漁 を続けた人が 4 時間以上の待機と回答したものと思われ る.

\section{4. 現地 調查}

\section{（1）現地調查の方法}

2003 年 11 月 12 日から 14 日までの 3 日間, 十勝沖地 震で津波が来襲した現地へ赴き，十勝沖地震津波に関す るヒアリング調査を行った，調査の目的は，漁業組合を 対象としたアンケート調査から得ることができなかった 漁業組合と漁民との関係，また，漁民は漁業保険に加入 しているにもかかわらず，なぜ地震時に危険を冒してま で，沖へ自船を避難させるのかという $2 つ の$ 事項を明ら かにすることであった. 調査日程は, 12 日に大津漁業組
合, 13 日午前に広尾漁業組合, 13 日午後にえりも町漁業 組合, 14 日午前に様似漁業組合をそれぞれ訪問し, ヒア リングを実施した。

\section{(2) 現地調查の結果}

a）地震時に漁業組合ではどのような対応をとるの 加

漁業組合は企業のような結束力を持たず，あくまで個 人経営の漁民の仲介を行っているような組織である。そ のため, 地震時に職員に対して対応を定めている組合は 少なく，まずは自分の身の安全の確保を行うことを優先 させているところが多い. 漁民への対応と同様に個人の 判断，または責任を重要視している表れだと思われる。 また，地震時に組合施設に集まるという取り決めがなさ れていても, 漁民への避難指示を行うことはせず, 安否 の確認に留まっている. 情報の伝達方法は, 携帯電話が 主流であり，漁業無線でのやり取りは，漁船同士に限ら れてきているようである.

漁民は漁業無線を 1 隻に数台搭載しているのが現状で ある. 表一2には, 漁業無線の設置状況を示した。この表 の見方は, 左から漁業無線機の設置状況を○×で示して いる. 次の空中線電波は, 無線の強さを表し, この值が 大きければより遠くまで無線を飛ばすことができる．ま た, 無線局名は, 職員が 24 時間滞在している無線局のこ とである. 取り扱う空中線電波が $200 \mathrm{~W}$ 程度というよう に，主に遠洋漁業者のために設けられたものである.

表一2 から，すべての漁業組合に無線機が設置されて いるわけではないことがわかる.この理由は, 沿岸部に おいては, 携帯電話を用いることにより, 漁船と漁業組 合間で情報伝達が可能であるためである。また, 漁業無 線を用いて組合と漁民との間の情報交換は，職員が勤務 している時間内のみという制約を受け, 携帯電話を主に 利用しているか, 職員が 24 時間駐在している漁業無線局 に委託しているためと考えられる。

この地震では, 漁業無線を用いて漁業組合から指示を 出したのは図一 3 に示したように 4 漁業組合のみであっ

表一2 漁業無線の設置状況

\begin{tabular}{|c|c|c|c|c|c|c|c|c|}
\hline 漁業組合名 & $\begin{array}{l}\text { 有無 } \\
\end{array}$ & \multicolumn{4}{|c|}{ 空中線電波 } & 無線局名 & \multicolumn{2}{|c|}{ 空中戦電波 } \\
\hline $\mathrm{a}$ & 0 & & & & & \multirow{3}{*}{ A } & $1 \mathrm{~W}$ & $6 \mathrm{~W}$ \\
\hline b & 0 & $1 \mathrm{~W}$ & & & & & $25 \mathrm{~W}$ & $50 \mathrm{~W}$ \\
\hline $\mathrm{c}$ & 0 & $1 \mathrm{~W}$ & & & & & $200 \mathrm{~W}$ & \\
\hline $\mathrm{d}$ & 0 & & & & & \multirow{5}{*}{ D } & $1 \mathrm{~W}$ & $25 \mathrm{~W}$ \\
\hline $\mathrm{e}$ & $x$ & & & & & & $50 \mathrm{~W}$ & $200 \mathrm{~W}$ \\
\hline $\mathrm{f}$ & $x$ & & & & & & $200 \mathrm{~W}$ & $250 \mathrm{~W}$ \\
\hline $\mathrm{g}$ & 0 & $1 \mathrm{~W}$ & & & & & & \\
\hline$\frac{\mathrm{g}}{\mathrm{h}}$ & 0 & $1 \mathrm{~W}$ & $6 \mathrm{~W}$ & $25 \mathrm{~W}$ & & & & \\
\hline $\mathrm{i}$ & $\mathrm{O}$ & $1 \mathrm{~W}$ & & & & \multirow{3}{*}{ I } & $25 \mathrm{~W}$ & $25 \mathrm{~W}$ \\
\hline j & $x$ & & & & & & $50 \mathrm{~W}$ & $200 \mathrm{~W}$ \\
\hline $\mathrm{k}$ & 0 & $1 \mathrm{~W}$ & $1 \mathrm{~W}$ & $6 \mathrm{~W}$ & $25 \mathrm{~W}$ & & & \\
\hline 1 & 0 & $1 \mathrm{~W}$ & & & & \multirow{8}{*}{$Z$} & $1 \mathrm{~W}$ & $6 \mathrm{~W}$ \\
\hline $\mathrm{m}$ & 0 & $1 \mathrm{~W}$ & & & & & $25 \mathrm{~W}$ & $50 \mathrm{~W}$ \\
\hline $\mathrm{n}$ & $x$ & & & & & & $125 \mathrm{~W}$ & \\
\hline 0 & $x$ & & & & & & & \\
\hline $\mathrm{p}$ & $x$ & & & & & & & \\
\hline$q$ & $x$ & & & & & & & \\
\hline $\mathrm{r}$ & $x$ & & & & & & & \\
\hline $\mathrm{s}$ & 0 & $1 \mathrm{~W}$ & & & & & & \\
\hline
\end{tabular}


た。また, 図一9に示したように帰港判断も漁民によって ばらつきがあった。携帯電話は, 災害時に輻輳する可能 性が非常に高いが, 漁業無線にはそのような心配がなく, 災害時には有効に活用できる情報手段であることが確認 できた．現在は，無線局から漁船に対して，帰港の指示 をしていないが, 陸上と情報交換ができる有効な手段で あるため, 安否確認や避難・帰港指示を出すことが可能 である. 将来的には, 無線局がそのような機能をもった 組織になるように，提言していくべきであろう.

b）漁業保険に加入しているのにも関らず，漁民はな ぜ地震時に危険を冒してまで沖へ自船を避難さ せるのか

2001 年度末の漁船普通保険の加入率 (農林統計協会, 2002) は, 全国平均で $63.3 \%$ あった。. 図一1に示したよ うに, 今回の調查地域における加入率は $91 \%$ であった. しかし, 地震時に危険を冒してまで自船を沖へ避難させ

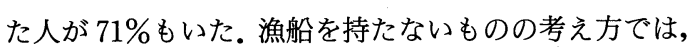
漁民の行動すべてを理解することはできないであろう が，保険金の給付率が 9 割程度であることに問題がある と思われる. 数千万円以上の漁船が全損した場合には, その 1 割負担であっても, 漁民にとっては重荷になるこ と, また, 商売道具である漁船が故障すると, 修理期間 中に収入が得られないのである。漁師仲間はいるが実際, 収入を得るのは自分自身であり, 誰も助けてはくれない ので, 是が非でも沖へ自船を避難させたいと考えるので あろう。しかし，津波に対して正しい知識を持たずに， 大地震が発生すると津波が来襲するという教訓にした がって行動しているので, 津波の来襲時間が短い場合に ついては，今回のような被害で斉むとは考えられず，人 的被害も発生するものと思われる. 漁船に損害が発生す れば, 収入に影響が出るのは理解できるが, 自己の生命 があってのことであるため, 正しい知識を持って避難す べきである.

\section{5. 結 語}

以上, 漁業組合や漁民へのアンケート調査および現地 調査から得られた, 地震時における漁民の行動および情 報伝達手段を以下にまとめてみる.

1）アンケート調査を行った地域における漁民の漁業 保険の加入率は $91 \%$ であり, これは全国平均の $63 \%$ に比 較しても非常に高い。それにも関わらず, 地震時に漁港 内に停泊していた漁船の避難率は $71 \%$ ありり, 漁民は危 険を冒して沖に自船を避難させた。この理由としては, 漁業保険の給付率が 9 割程度であり, 数千万円以上の漁 船が全損した場合には，その 1 割負担であっても漁民に
とっては重荷になること, 漁船の修理期間中には, 収入 がなくなることなどが挙げられる.2）地震発生時に漁業 組合から漁民に対して, 何らかの情報伝達がなされたの は, 18 組合のうち, 7 組合に留まり, 半数にも達してい ない。この理由は, 津波の来襲に対して情報を伝達する 時間的な余裕がないことのほかに, 漁船避難は漁民個人 で判断することであり，漁業組合が関与すべきではない と考えているためである.これを裏付けるように, 避難 マニュアルの作成は 2 漁業組合のみに留まり, 津波避難 訓練も 5 漁業組合でしか実施されていない.3）多くの漁 船に数台の漁業無線機が搭載されているにも関わらず, 出漁中の漁民と漁業組合との情報伝達手段として, 災害 時には輻軼する可能性が非常に高い携帯電話を漁業無線 よりも頻繁に用いている．4）避難した漁民の帰港時間 も, 個人の判断に委ねられているため, 畄港時間は漁民 ごとに異なり,洋上で情報から孤立した漁民にとっては, 帰港の際に危険が伴う.5）北海道では, 職員が 24 時間常 駐する漁業無線局が存在する. そのため, これに加入す れば, 自己の漁業組合に職員がいない時間帯に地震が発 生しても, 避難漁民に情報伝達ができ, 災害時の漁業無 線の有用性が確認できた. 6) 地震発生直後にすべての漁 民が, 漁港に駆けつけるわけではない.漁港に行かなかっ た漁民のうち， 6 割は漁船価格が 100 万円以下のもの, 8 割が 2 トン以下の所有者である.7）図一6 および 7 に示 すように，すべての漁民が過去の教訓にしたがって自船 を避難させてはいない. 漁民の多くは, 地震発生後, 漁 港に行き, 自分の目で漁船の様子を見てから, 自船を避 難させるか否かを決定している.8）避難地点の水深とし ては, $20 \mathrm{~m} \sim 30 \mathrm{~m}$ 程度であれば, 津波を感じることなく, 洋上で安全に避難できる。

謝辞 : アンケート調査の実施に際して, 農林水産省水 産庁の中村克彦氏, 北海道開発局帯広開発建設部の根本 任宏氏ならびに牧田佳巳氏に大変お世話になった。また， アンケート調査およびヒアリング調查に協力していただ いた多くの漁業組合の関係各位に感謝の意を表します。

\section{参 考 文 献}

早瀬吉雄・宮本義憲（1984）：日本海中部地震津波に上る熊石漁 港内の水理現象と沵船避難への影響に関する研究, 土木試験 所月報, No. 736, pp. 19-32.

山本正昭・ 中山哲嚴 坂井 淳・ 三橋宏次 (1985): 日本海中部 地震津波による漁港内の漁船被害, 第 32 回海岸工学講演会 論文集, pp. 460-464.

河田恵昭·長谷川茂樹(1994)：地震津波警報の伝達と避難マニュ アルについて, 海岸工学論文集, 第 41 巻, pp. 1186-1190.

農林統計協会 (2002): 図説水産白書 平成 14 年度, 農林統計協 会, p. 112. 